\title{
航研機の開発と流れの可視化*
}

谷田好通**

\section{Trial Aircraft "Kokenki" and Flow Visualization}

\section{Yoshimichi TANIDA}

田古里会長より航研機について書くようにお話 のあったのは大分以前のことです。田古里先生は 流れの可視化は言らまでもなく航空機のソリッド モデルの権威（東京ソリッドモデルクラブ会長） ですので，この記事を書くのに最適な方ではない かと思いますが，航研育ちといらことで私に拈鉢 がまわってきたといら次第です。

さて, 東京大学航空研究所 ${ }^{11}$ は 1918 年に航空の 発展に対寸る国家的期待が急に高末りつつあっ た社会的情勢を背景にして設立されましたが， 1932年航空研究の活性化のために世界記録を狙う 飛行機の設計・製作といら当時としては思い切 ったプロジェクトが企画されました。記録の目標 としては当時世界的競走の的であった航続距離が 選ばれ，1933年に予算化（政府出資額は総額49万 円)，1935年に基礎設計を終了，1937年に機体が 完成しました。これが航研機（航空研究所長距離 機の略) です（写真 1 : 全長 $15.06 \mathrm{~m}$, 全幅 27.93 $\mathrm{m}$, 自重 $4225 \mathrm{~kg}$, 全備重量 $9200 \mathrm{~kg})^{1)}$ 2) 2 年間 飛行試験が行われましたが，その間1938年 5 月 13 日から 5 月 15 日にかけて千葉県木更津（旧海軍飛 行場） $\rightarrow$ 群馬県太田（旧中島飛行機）－神奈川県

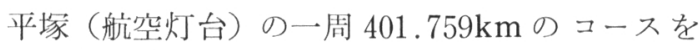
周回して $11851 \mathrm{~km}$ を飛び, 当時の航続距離の世 界記録を樹立してパリにある国際航空連盟(FAI) より公認されました。しかし航研機の機体は第 2 次大戦後進駐軍によって廃棄されたといらことで すし，また世界記録の認定証も本物は終戦からこ

*原稿受付 1989 年 7 月 5 日

**正会員 東京大学先端科学技術研究センタ一

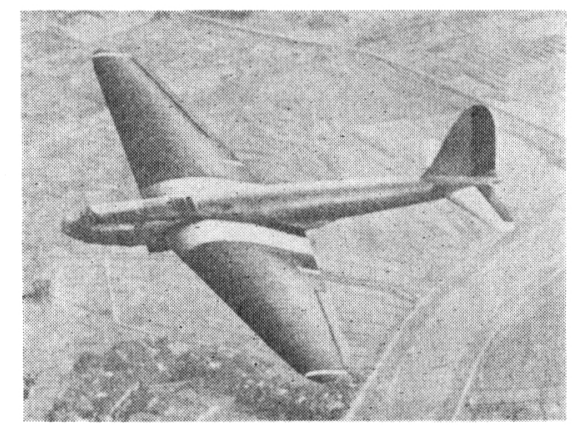

写真 1 関東平野を周回飛行中の航研機（朝日新聞社撮影）

の方の何回かの研究所の組織替觉のどさくさで現 在行方不明になっていることは非常に残念なこと です。

航研機がこのような記録をたてることができた のは当時の最先端技術が駆使されたからです。翼 の一部は羽布張でしたが内翼, 胴体, 尾翼などは 超ジェラルミン構造で沈頭鋲が用いられました。 さらに脚は完全引込式で操縦席の風防も折畳又式 で極力抵抗を減らす努力がなされています。エン ジンは当時陸軍の実用機に多く使われていた川崎 航空機工業の BMW 9 型715馬力水冷ガソリンェ ンジン $\left(12\right.$ 気筒 $60^{\circ} \mathrm{V}$ 型, 総行程容積 $46.9 l$, 圧縮 比 7.3）を改造したものです。その結果, 空然比 17-19 といら極めて薄い混合気で巡行運転するこ とが可能となり，燃料消費率 $175 \mathrm{gr} / \mathrm{HPhr}$ (1600 $\mathrm{rpm}$ ) が得られ，航研機の世界記録樹立に大きく 寄与しました。

以上のよらに航研機は当時の最先端の技術で作 られたわけですが，その基礎的な研究には流れの 


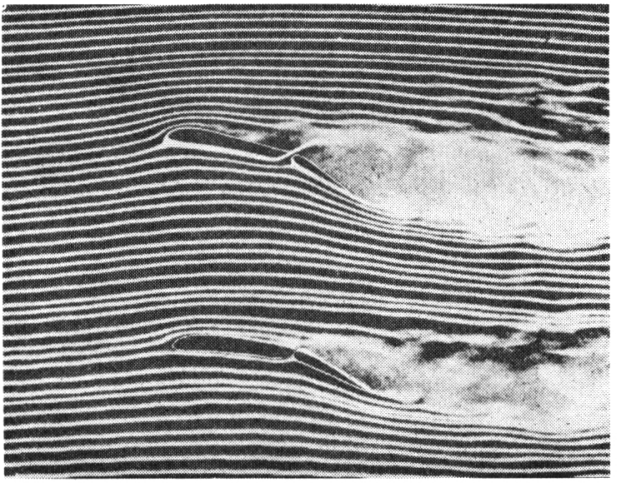

写真 2 複葉翼を過ぎる気流（ミスト法）

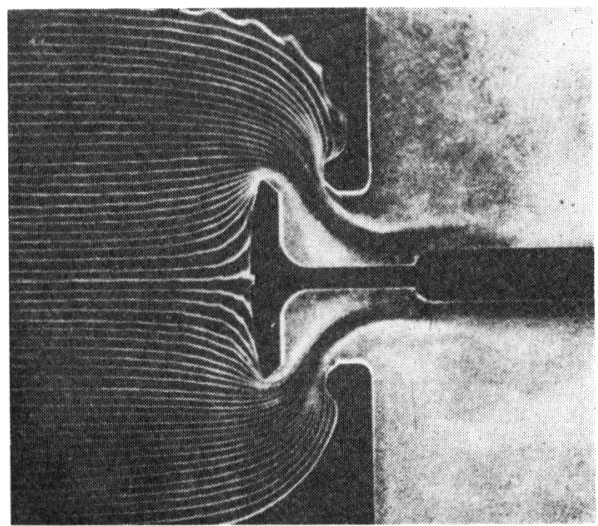

写真 3 排気弁より出る気流 (ミスト法)

可視化孔積極的に使われていたようで，写真 2 一 4はそれらの例です。これらの写真は交通博物館 の肥沼恵一氏より提供(田古里先生の依頼に上る) していただいたもので，航研機の記録樹立記念の パンフレット（記念絵葉書?) に収められていた ものです。これを見ますと，現在とあまり変わら

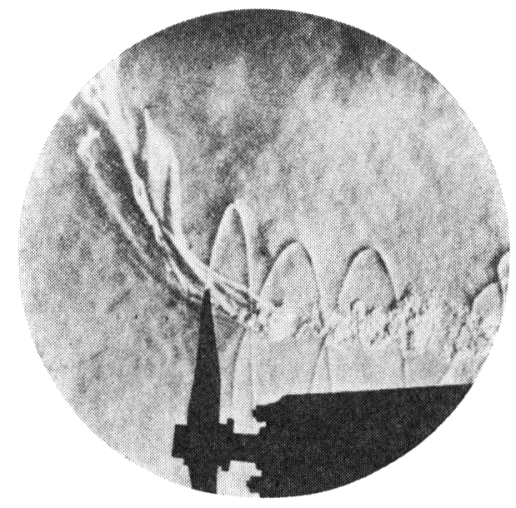

ラセン状の線は翼端渦, 白煙状のものは加熱した 空気の流丸

写真 4 プロペラ付近の父流（シュリーレン法）

ない活どの技術で可視化が行われていたのには感 心します。航研機の経験はその後「A-26 長距離 機」に引継がれて1944年に $16435 \mathrm{~km}$ の航続距離 世界記録が達成され (戦時中のため未公認), ま たこれらの技術は高速度飛行にも凝縮されて試作 の「研三機」は1943年にピストンェンジン機とし ては刮目すべき $699.9 \mathrm{~km} / \mathrm{h}$ の飛行速度を達成し て拈ります。

流れの可視化が刺身のつまになってしまいまし たが，多少でもご参考になれば幸甚であります。 最後に写真を提供していただきました肥沼恵一氏 に感謝を申し上げます。

\section{参考文献}

1）東京大学百年史, 第 6 巻部局史 N $N(1980)$.

2) 山本峰雄：航空研究所長距離機, 航空情報 (1959.4), p. 80. 